\title{
ESTIMATION OF CAPITAL OF AGRO-INDUSTRIAL ENTERPRISES AS AN ECONOMIC RESOURCE
}

\author{
Nadiia Davydenko ${ }^{1}$ Prof. dr. hab.; Olha Kliuchka2 PhD; Julia Kulbach ${ }^{2}$ PhD student \\ ${ }^{1}$ National University of Life and Environmental Science of Ukraine; ${ }^{2}$ University of State Fiscal Service of Ukraine
}

Abstract. Modern management of agroholding is based not only on the management of its economic activity but capital management in order to maximize it as as well. The possibility of a systematic calculation of the aggregate capital value for the purpose of strategic management gives a clear understanding of the correct way of further development in which the company is located. Therefore, the purpose of the article is to determine the amount of aggregate capital, its structure in leading agroholdings of Ukraine, and on the basis of analytical studies of the development of proposals for the possibility of increasing the aggregate capital value. The achievement of the research goal was based on a systematic approach and a comparative economic analysis. During the study quantitative and structural analysis of processes and phenomena was applied.

The study made it possible to establish that for 2010 - 2017 there is a clear tendency to increase the size of aggregate capital of agroholdings, what is connected with the growth of the volume of own capital. The share of equity in agroholdings increased due to the growth in the amount of reserve capital and retained earnings. The practical value of the results obtained is determined by the fact that the conclusions and proposals can be used to more accurately and objectively calculate the value of enterprises, which in turn can become the basis for making optimal financial decision. This material can be used to make strategic management decisions by managers of agricultural holdings.

Keywords: capital, total capital, structure of capital, equity, profitability.

JEL code:D23, Q13, Q14

\section{Introduction}

Taking into account Ukraine's aspiration to become a part of the EU, and in conditions of European integration and free trade, products of domestic producers of agricultural products should be highquality and competitive.Under such conditions, the effective operation of agroholdings isn't possible without increasing the equity capital and attracting it from the outside. After all, market value, financial stability and solvency of the enterprise, the level of risk of investment activity of enterprises depends on the efficient management of capital.

The category "capital" is one of the fundamental and rather complex, and its content has been developed in the scientific works of O. Bem-Bawerk, M. Blauga, F. Wieser, C. Wicksell, K. Marx, C. Menger, W. Petty, D. Ricardo, A. Smith, D. Hicks and others. In the writings of the above authors, the basic categories of the studied scientific issues are considered, the classification of capital expands, the methodological bases of its evaluation are improved, the mechanisms for ensuring the efficiency of the formation and use of capital are developed. At the same time, conceptual questions regarding the basic economic logic of determining the effectiveness of capital management and its evaluation are considered fragmentary.

An assessment of the capital structure is one of the most important and complex tasks that are being solved in the financing process. An immediate response to changes in the external and internal environments requires a significant upgrade of many management functions. In this connection, the role of analysis is growing first of all.

The analysis allows determining the optimal structure of enterprise capital. At the same time, the interaction of the subjects of a market economy is primarily due to economic interest - an increase in the economic efficiency of the activity. After all, the most effective management of financial resources can be achieved using a policy of asset financing, the main objectives of which is to increase their profitability. Much of the theoretical development of the analysis of the structure of capital, as a branch of knowledge, does not take into account combinatorial methods for analysing both 
empirical and static data, eliminating the disadvantages of historical analysis. The relevance of the problem identified the purpose and objectives of this article.

Therefore, the purpose of the article is to determine the amount of aggregate capital, its structure in leading agroholdings of Ukraine, and on the basis of analytical studies of the development of proposals for the possibility of increasing the aggregate capital value.

Main research objectives:

- to determine the dynamics of the aggregate capital amount of leading agriholdings in Ukraine and to determine the reasons that led to changes in its value;

- analyse the shares of the main components of the aggregate capital of agricultural holdings;

- analyse the efficiency of using agroholdings of the total capital.

Information sources: scientific articles available in international editions, annual financial reports of leading agroholdings of Ukraine.

Based on the financial statements of Ukraine's agroholdings, the dynamics of aggregate capital, its structure, and the profitability of equity capital of leading agroholdings were calculated.

The achievement of the research goal was based on a systematic approach and a comparative economic analysis. During the study quantitative and structural analysis of processes and phenomena was applied.

Questions of the assessment of capital and its importance for the effective operation of agricultural holdings were considered in the works of N.O. Kurovskaya (Kurovskaya N., 2014), who explores the essence and theoretical $n$ ' methodological substantiation of the formation of agricultural enterprises capital. Nazarenko I. M. and Orehova A.I. (2015) explore the current state of capital provision of agricultural enterprises in Ukraine and its structure. O.O. Lelyuk examines the main criteria for optimizing the capital structure of agrarian enterprises (Lelyuk O., 2010). We consider this issue to be very relevant and necessary for further research.

\section{Research results and discussion}

Successful activity of business entities in any type of ownership depends on the availability of capital and the efficiency of its use, after all, capital is the basis of the production process since it determines the financial potential. Capital is a basic component of the success of any business, provided that the main purpose of the business is long-term economic growth.

The size of capital is not only a formal criterion for assessing enterprise sustainability but also a subjective characteristic of owners' confidence in their business since they have invested in their own funds (Nazarenko I., Orehova A., 2015). All this gives us reason to say once again that the issue of capital adequacy is relevant.

So as determine the real volume of aggregate capital, we propose to consider the dynamics of the aggregate capital of Ukrainian agroholdings in the dynamics in order to find out the main trends (Table 1).

The data in Table 1 gives reason to assert that in 2014 all investigated agroholdings increased the amount of aggregate capital, which testifies to their successful and productive activity. The turning points were 2014 and 2015 - the time of severe economic upheavals in Ukraine, which negatively affected the value of the aggregate capital of all leading agroholding. 
The dynamics of the aggregate capital of Ukrainian agroholdings

in 2010-2017 (millions of \$)

\begin{tabular}{|c|c|c|c|c|c|c|c|}
\hline \multirow{9}{*}{$\begin{array}{l}n \\
\stackrel{n}{\pi} \\
\stackrel{2}{\nu}\end{array}$} & & Kernel & Astarta & Milkiland & Avangard & IMC & MHP \\
\hline & 2010 & 1124.8 & 352.6 & 267.9 & 1079.0 & 87.4 & 1574.0 \\
\hline & 2011 & 1572.6 & 567.9 & 327.7 & 1305.7 & 138.7 & 1944.4 \\
\hline & 2012 & 2119.0 & 636.4 & 324.4 & 1578.3 & 244.5 & 2488.1 \\
\hline & 2013 & 2366.9 & 693.0 & 336.5 & 1818.9 & 361.9 & 2768.1 \\
\hline & 2014 & 1919.0 & 506.5 & 239.9 & 1038.3 & 183.8 & 2293.5 \\
\hline & 2015 & 1465.6 & 491.6 & 186.6 & 624.1 & 174.6 & 2075.7 \\
\hline & 2016 & 1509.3 & 574.6 & 168.5 & 529.5 & 158.9 & 2075.9 \\
\hline & 2017 & 2009.1 & 533.3 & 160.4 & 512.8 & 180.1 & 2278.1 \\
\hline \multirow{2}{*}{ 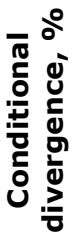 } & $2017 / 2016$ & 33.1 & -7.2 & -4.8 & -3.2 & 13.3 & 9.7 \\
\hline & $2017 / 2010$ & 78.6 & 51.2 & -40.1 & -52.5 & 106.0 & 44.7 \\
\hline
\end{tabular}

Source: author's calculations based on financial statements of agroholdings

In particular, Milkiland and Avangard reduced their equity by more than $60 \%$, Kernel reduced its equity by almost $14 \%$, and MHP by about $30 \%$. Another situation is observed in the Astarta holding company, which has an increase in own capital by $9 \%$, but at the same time the size of the current obligations of the holding is growing by $34 \%$, accordingly, this is not enough to cover the reduction of long-term obligations by $73 \%$. The volume of obligations of "IMC" decreased by $55 \%$, so this agroholding was the most successful of the sample.

Starting from 2016, the dynamics of aggregate capital shows an increase, what indicates an improvement in the level of financial stability in agroholdings: «Kernel» - by $33 \%$, «IMC» - by $13 \%$, «MHP» - by $9.74 \%$, by increasing equity and long-term liabilities.

However, we are convinced that the efficiency of an enterprise depends on the rational use of available capital. After all, following certain proportions of equity and borrowed capital, it is possible to ensure the solvency of the enterprise, the necessary level of financial independence and profitability (Koshelyok V., Tereschenko O., 2016).

Therefore, we will further analyze the structure of equity and borrowed capital on the basis of the financial statements of leading agroholdings (Table 2).

As we see, according to Table 2, the structure of capital of leading agroholdings in Ukraine has changed. Thus, «Astarta», «Milkiland», «IMC», «MHP» increased their share of equity by 2017. Equity of the share capital of Astarta Agroholding increased by $24 \%$ due to the growth in retained earnings. In "Milkiland", reserve capital increased by $14.7 \%$. an increase in the amount of equity capital "IMC" is associated with the implementation of the "Plan for stimulating management", in which the issue of shares led to an increase in authorized capital by $\$ 3$ million. The equity growth in "MHP" is due to an increase in retained earnings almost by $30 \%$ and a reserve capital by $16 \%$.

For a more detailed assessment of the capital of leading Ukrainian agroholdings, we propose to analyse the efficiency of the use of aggregate capital, as an important indicator in determining the financial condition of the enterprise is the indicator of profitability. Profitability as a general indicator of the economic efficiency of agricultural production reflects the efficiency of the resources consumed by the industry. 


\section{Analysis of the structure of the capital of agricultural holdings} in $\mathbf{2 0 1 0 - 2 0 1 7 , \%}$

\begin{tabular}{|c|c|c|c|c|c|c|c|c|c|c|}
\hline \multirow{2}{*}{ Indicator } & \multicolumn{8}{|c|}{ Years } & \multicolumn{2}{|c|}{$\begin{array}{l}\text { Conditional } \\
\text { divergence }\end{array}$} \\
\hline & 2010 & 2011 & 2012 & 2013 & 2014 & 2015 & 2016 & 2017 & $\begin{array}{c}2017 / \\
2016 \\
\end{array}$ & $\begin{array}{r}2017 / \\
2010 \\
\end{array}$ \\
\hline \multicolumn{11}{|c|}{ Kernel } \\
\hline $\begin{array}{l}\text { Equity } \\
\text { capital }\end{array}$ & 53.8 & 63.4 & 57.1 & 57.1 & 53.7 & 60.8 & 66.1 & 57.6 & -8.4 & 3.8 \\
\hline $\begin{array}{l}\text { Borrowed } \\
\text { capital }\end{array}$ & 46.2 & 36.6 & 42.9 & 42.9 & 46.3 & 39.2 & 33.9 & 42.4 & 8.4 & -3.8 \\
\hline $\begin{array}{l}\text { Long-term } \\
\text { liabilities }\end{array}$ & 14.9 & 11.5 & 21.7 & 13.1 & 15.2 & 8.0 & 9.2 & 27.8 & 18.5 & 12.8 \\
\hline \multicolumn{11}{|c|}{ Astarta } \\
\hline $\begin{array}{l}\text { Equity } \\
\text { capital }\end{array}$ & 59.3 & 54.1 & 51.5 & 53.5 & 43.5 & 48.9 & 61.5 & 65.2 & 3.7 & 5.9 \\
\hline $\begin{array}{l}\text { Borrowed } \\
\text { capital }\end{array}$ & 40.7 & 45.9 & 48.5 & 46.5 & 56.5 & 51.1 & 38.5 & 34.8 & -3.7 & -5.9 \\
\hline $\begin{array}{l}\text { Long-term } \\
\text { liabilities }\end{array}$ & 19.3 & 22.6 & 26.9 & 19.2 & 24.4 & 6.7 & 12.9 & 11.1 & -1.9 & -8.3 \\
\hline \multicolumn{11}{|c|}{ Milkiland } \\
\hline $\begin{array}{l}\text { Equity } \\
\text { capital }\end{array}$ & 45.9 & 50.6 & 55.1 & 52.1 & 39.4 & 19.3 & 4.1 & 8.1 & 4.0 & -37.8 \\
\hline $\begin{array}{l}\text { Borrowed } \\
\text { capital }\end{array}$ & 54.1 & 49.4 & 44.9 & 47.9 & 60.6 & 80.7 & 95.9 & 91.9 & -4.0 & 37.8 \\
\hline $\begin{array}{l}\text { Long-term } \\
\text { liabilities }\end{array}$ & 31.5 & 22.6 & 24.0 & 15.5 & 10.0 & 10.8 & 16.0 & 15.4 & -0.7 & -16.1 \\
\hline \multicolumn{11}{|c|}{ Avangard } \\
\hline $\begin{array}{l}\text { Equity } \\
\text { capital }\end{array}$ & 69.2 & 71.9 & 74.0 & 79.6 & 62.2 & 37.7 & 26.2 & 16.5 & -9.7 & -52.7 \\
\hline $\begin{array}{l}\text { Borrowed } \\
\text { capital }\end{array}$ & 30.8 & 28.1 & 26.0 & 20.4 & 37.8 & 62.3 & 73.8 & 83.5 & 9.7 & 52.7 \\
\hline $\begin{array}{l}\text { Long-term } \\
\text { liabilities }\end{array}$ & 22.0 & 16.8 & 13.1 & 14.5 & 7.9 & 47.8 & 65.0 & 14.4 & -50.6 & -7.7 \\
\hline \multicolumn{11}{|c|}{ IMC } \\
\hline $\begin{array}{l}\text { Equity } \\
\text { capital }\end{array}$ & 76.9 & 78.6 & 52.4 & 42.5 & 14.8 & 34.4 & 40.9 & 57.8 & 16.8 & -19.1 \\
\hline $\begin{array}{l}\text { Borrowed } \\
\text { capital }\end{array}$ & 23.1 & 21.4 & 47.6 & 57.5 & 85.2 & 65.6 & 59.1 & 42.2 & -16.8 & 19.1 \\
\hline $\begin{array}{l}\text { Long-term } \\
\text { liabilities }\end{array}$ & 13.7 & 12.4 & 19.7 & 14.1 & 38.4 & 25.5 & 36.3 & 17.2 & -19.1 & 3.4 \\
\hline \multicolumn{11}{|c|}{ MHP } \\
\hline $\begin{array}{l}\text { Equity } \\
\text { capital }\end{array}$ & 42.6 & 47.6 & 48.2 & 45.1 & 41.2 & 32.4 & 33.4 & 43.3 & 9.9 & 0.7 \\
\hline $\begin{array}{l}\text { Borrowed } \\
\text { capital }\end{array}$ & 57.4 & 52.4 & 51.8 & 54.9 & 58.8 & 67.6 & 66.6 & 56.7 & -9.9 & -0.7 \\
\hline $\begin{array}{l}\text { Long-term } \\
\text { liabilities }\end{array}$ & 42.0 & 36.6 & 33.0 & 43.0 & 40.1 & 49.6 & 48.3 & 50.0 & 1.8 & 8.0 \\
\hline
\end{tabular}

Source: author's calculations based on financial statements of agroholdings

Figure 1 shows the dynamics of the profitability indicator of aggregate capital of agroholdings for 2010-2017.

It shows approximately the same trend in all investigated agroholdings. Profitability of aggregate capital tends to decrease since 2013, due to the reduction of net profit, in 2014 all investigated agroholdings were loss-making, so the profitability of all leading agroholdings was negative. In 2015, the situation was better, aggregate capital of agricultural holdings has been used more effectively. 


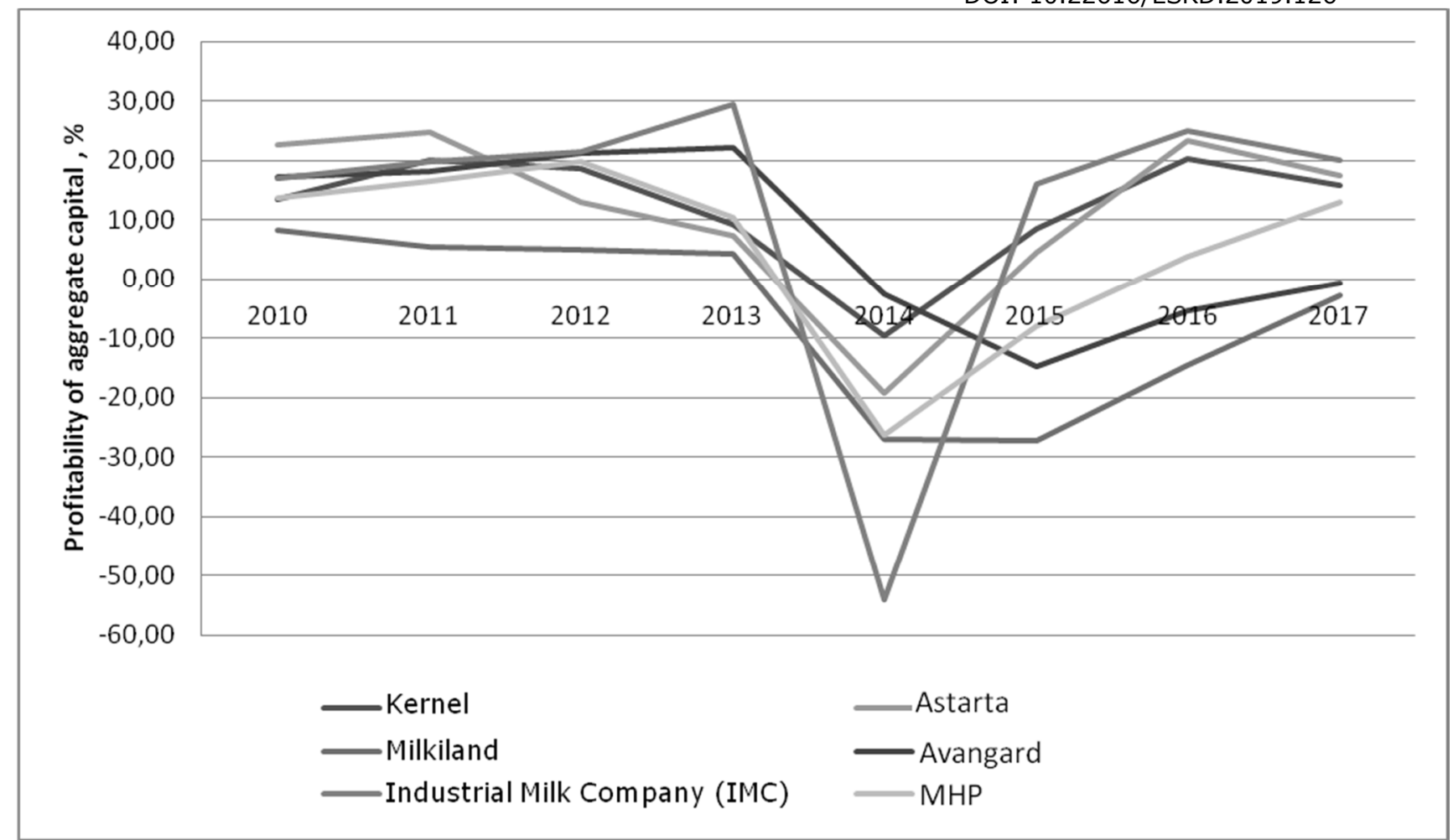

Source: author's calculations based on financial statements of agroholdings

Fig. 1. Dynamic of profitability of aggregate capital of the Ukrainian agroholdings since 2010 to 2017

At the end of 2017, three agroholdings achieved a growth in the return on aggregate capital, in particular, Milkiland increased the indicator by $11.8 \%$, the net loss of the holding fell by $81 \%$, due to the fact that Milkiland concentrated its efforts on the sale of dairy products with high added value, as well as new export markets.

The profitability of the aggregate capital of the agroholding Avangard increased by $4.6 \%$ and amounted to $-0.7 \%$, while the Avangard holding managed to reduce its net loss by $87 \%$. The operational activity of the "Avangard" agroholding was positively influenced by the seasonal growth in demand and prices for eggs in Ukraine, optimization of the cost price by updating the livestock, which led to increased productivity. The profitability of MHP's aggregate capital increased by $9.2 \%$, what is the result of the profiTable activity of the company. Thus, according to the financial statement of agroholdings in 2017, it received 204 million dollars of net profit, what is by 3.4 times more than in 2016.

However, a number of investigated agroholdings reduced the profitability of aggregate capital by reducing the amount of net profit, including Kernel by $4.2 \%$, IMS by $5 \%$, Astarta by $5.9 \%$, what indicates an ineffective policy of managing capital in a post-crisis period and needs to develop proposals to address identified gaps.

\section{Conclusions, proposals, recommendations}

1) The conducted research gives grounds to assert that the value of aggregate capital of agroholdings is gaining a tendency to increase. It is established that this is due to an increase in the volume of equity. Starting from 2016, the dynamics of aggregate capital shows an increase, what indicates an improvement in the level of financial stability in agroholdings: «Kernel» - by $33 \%$, «IMC» by $13 \%$, «MHP» - by $9.74 \%$.

2) Most of the leading Ukrainian agroholdings have increased their share of equity, while in half of them, the share of equity in the aggregate structure is more than $50 \%$. This indicates that the 
leading Ukrainian agroholdings use mostly internal sources of financing, in particular, retained earnings and reserve capital. We believe that this aspect is positive because it indicates an increase in the level of financial independence and the stability of agroholdings.

3) However, for those agroholdings that have reduced the profitability of equity, we recommend the following measures:

- it is expedient for financial managers to consider the possibility of using along with internal and external sources of funding because attracting debt capital will significantly increase the financial potential of the enterprise due to the formation of an additional volume of assets;

- carry out continuous monitoring of the structure of the holding's capital in order to achieve the optimal balance between own and borrowed capital and maintain this ratio at the appropriate level.

The results of the analysis of the structure of the capital of agricultural holdings in Ukraine make it possible to assess the financial risk of attracting external sources of capital, establish a profile of the term of payments (regulation of dividend payments), refinancing the risks associated with the structure of debt, as well as the duration and ratio of short-term and long-term indebtedness.

\section{Bibliography}

1. Davydenko N.M. (2012). Financial Management. Kiev.

2. Kirsanova T., Kolyada N. (2010). Enterprise Equity Management System. Sumy State Bulletin the University. Series: Economics.1, Volume 2, pp. 58-63.

3. Kurovskaya N. (2014). Formation of Capital in the Process of Securing Financial Activity of Agricultural Enterprises. Bulletin of ZNAMEU.1-2 (43), Volume 2, pp. 170-176.

4. Lelyuk O. (2010). Optimization of the Capital Structure of Agrarian Enterprises. Agrosvit, Volume 21, pp. 36-41.

5. Moskalenko V., Plastun O. (2013). Comprehensive Assessment of the Financial Condition of the Company as a Basis for Diagnosing its Bankruptcy. Actual Problems of the Economy, Volume 6, pp. 181-191.

6. Nazarenko I., Orekhov A. (2015). Analysis of the Current State of Provision of Capital to Agricultural Enterprises in Ukraine. Scientific Herald of Uzhhorod National University, Vol. 4, pp. 56-61.

7. Wallets V., Tereshchenko O. (2016). Optimization of the Ratio of Own and Borrowed Capital of the Enterprise. Scientific Herald of Kherson State University, Volume 21, ch.1, pp. 116-121. 